\title{
Hubungan antara Minat Belajar dan Hasil Belajar Matematika Siswa SMA Kristen Eben Haezer Ibu dengan Menggunakan Analisis Regresi
}

\author{
Noveriana Kristi Bunga ${ }^{1}$, Jantje Prang ${ }^{2}$, Nelson Nainggolan ${ }^{3}$ \\ ${ }^{1}$ Program Studi Matematika, FMIPA, UNSRAT Manado, Noverianabunga404@yahoo.co.id \\ ${ }^{2}$ Program Studi Matematika, FMIPA, UNSRAT Manado, jdprang@yahoo.com \\ ${ }^{3}$ Program Studi Matematika, FMIPA, UNSRAT Manado, bapaivana@yahoo.co.id
}

\begin{abstract}
Abstrak
Minat belajar dan hasil belajar siswa merupakan hal yang sangat penting untuk dikembangkan. Dengan adanya minat belajar dalam diri siswa akan membuat siswa terdorong untuk menyenangi aktifitas khususnya pada pelajaran matematika, yang berpengaruh pada hasil belajar matematika. Dengan demikian hasil belajar yang baik tidak sepenuhnya tergantung pada tingkat kecerdasan intelektual siswa. Hasil analisis hubungan antara minat belajar dan hasil belajar matematika siswa SMA Kristen Eben Haezer Ibu diperoleh nilai koefisien korelasi $\mathrm{r}=0.063$ untuk kelas XI IPA dan $\mathrm{r}=0.303$ untuk kelas XI IPS. Uji hipotesis, kelas XI IPA dan kelas kelas XI IPS secara statistika menyatakan tidak ada hubungan secara signifikan antara minat belajar dan hasil belajar matematika.
\end{abstract}

Kata Kunci : Regresi, Relasi

\section{The Relationship between Passion in Mathematics Learning and Their Ontcomes of Students' of Eben Haezer Christian High School in Ibu using Regression Analysis}

\begin{abstract}
Abstrack
Passion of studies and outcomes of students are very important to be improved learning passion in their soul encourages student to love learning actinties especially mathematicos which then can imprue their outcomes in math. Eventually good outcomes do not merely depend on studens' intellectual intelhigence. Relation analysis betureen of studies and outcomes of students of Eben haezer christian Ibu shows value of correlation coefficien $r$ $=0.0363$ for science class at XI and $r=0.303$ for social class at level XI. Hipotetical test shows that science class and social class statistically don't have significant relation betwreenpassion of study and outcomes.
\end{abstract}

Key Words : Regreation, Relations

\section{Pendahuluan}

Pendidikan merupakan suatu bentuk upaya yang dilakukan untuk menjadikan Indonesia yang berkualitas dan berdaya saing tinggi dalam menghadapi era globalisasi serta dalam menunjang pembangunan bangsa. Berbagai upaya dilakukan manusia untuk memperoleh ilmu pengetahuan melalui pendidikan karena dengan ilmu pengetahuan yang diperoleh manusia akan berkembang.

Dalam penelitian ini, minat belajar dan hasil belajar siswa merupakan hal yang sangat penting untuk dikembangkan. Dengan adanya minat belajar dalam diri siswa akan membuat siswa terdorong untuk menyenangi aktifitas khususnya pada pelajaran matematika, yang berpengaruh pada hasil belajar matematika, sehingga hasil belajar yang baik tidak sepenuhnya tergantung pada tingkat kecerdasan intelektual siswa.

Minat merupakan suatu rasa suka dan rasa ketertarikan pada suatu hal atau aktivitas, tanpa ada yang menyuruh dan cenderung untuk memberikan perhatian yang lebih besar terhadap hal atau aktivitas tersebut [1].

Hasil belajar merupakan realisasi atau pemekaran dari kecakapan-kecakapan potensial atau kapasitas yang dimiliki seseorang. Di sekolah hasil belajar ini dapat dilihat dari penguasan siswa akan melakukan pelajaran yang ditempuhnya. Tingkat penguasaan pelajar atau hasil belajar dalam mata 
pelajaran tersebut disekolah dilambangkan dengan angka-angka atau huruf, seperti 0-10 pada pendidikan dasar dan menengah dan huruf A, B, C, D dan E pada pendidikan tinggi [2].

Dalam mata pelajaran matematika di SMA Kristen Eben Haezer Ibu, Kabupaten Halmahera Barat Kecamatan. Ibu Utara, untuk setiap proses pembelajaran masih rendah termasuk minat belajar matematika. Dalam hal ini mempengaruhi hasil belajar siswa sekolah tersebut.

\section{Analisis Regresi Linier Sederhana}

Analisis regresi ini digunakan untuk memperkirakan nilai dari variabel tidak bebas (Y) pada nilai variabel bebas $(\mathrm{X})$ tertentu, sehingga dapat diketahui berapa besar pengaruh suatu variabel terhadap variabel lainnya. Setiap perubahan variabel bebas $(\mathrm{X})$ akan diimbangi dengan perubahan variabel tidak bebas $(\mathrm{Y})$.

Adapun persamaan garis regresi linier sederhana adalah sebagai berikut [3]:

dimana: $\beta_{0}=$ intersep (konstanta)

$$
\mathrm{Y}_{\mathrm{i}}=\beta_{0}+\beta_{1} X_{i}+\varepsilon_{i} \quad ; \quad i=1,2,3, \ldots n
$$

$\beta_{1}=$ koefisien regresi

$Y_{i}=$ Variabel tidak bebas

$X_{i}=$ Variabel bebas

$e_{i}=$ Error term

Untuk mendapatkan penduga yang baik bagi parameter regresi $b_{0}, b_{1}$, kita akan menerapkan metode kuadrat terkecil. Untuk setiap amatan contoh metode kuadrat akan menggunakan simpangan $Y_{i}$ dari nilai harapannya dengan hanya dua peubah bebas, persamaan regresi contohnya menjadi $\widehat{Y}=b_{0}+b_{1} x_{i}$ dan setiap pengamatan memenuhi hubungan $\widehat{y}_{1}=b_{0}+b_{1} X$ nilai dugaan kuadrat terkecil $\mathrm{b}_{0}$ dan $\mathrm{b}_{1}$ dapat diperoleh dengan memecahkan persamaan linear simultan [3],

$$
\begin{aligned}
& n b_{0}+b_{1} \sum_{i=1}^{n} x_{1 i}=\sum_{i=1}^{n} y i \\
& b_{0} \sum_{i=1}^{n} x+b_{1} \sum_{i=1}^{n} x_{1 i}^{2}=\sum_{i=1}^{n} x_{1_{i}} \mathrm{x}_{\mathrm{i}}
\end{aligned}
$$

\section{Metodologi Penelitian}

Penelitian ini merupakan penelitian survey yang sifatnya korelasional. Metode yang digunakan dalam penelitian ini adalah metode survey dimana kita melihat hubungan antara minat belajar dan hasil belajar matematika siswa SMA Kristen Eben Haezer Ibu tahun ajaran 2014/2015.

\subsection{Tempat dan Waktu Penelitian}

Penelitian dilaksanakan di SMA Kristen Eben Haezer Ibu Kabupaten Halmahera Barat, Kecamatan Ibu di Desa Goin, pada bulan Februari sampai Maret 2015.

\subsection{Populasi dan Sampel Penelitian}

Populasi dalam penelitian ini adalah seluruh siswa SMA Kristen Eben Haezer Ibu Kabupaten Halmahera Barat yang terdiri dari 280 siswa sedangkan sampel adalah seluruh siswa kelas XI berjumlah 55 siswa, yang terdiri dari 30 siswa kelas XI IPS dan 25 siswa kelas XI IPA.

\subsection{Variabel Penelitian}

1. Minat belajar matematika (X), sebagai perilaku siswa untuk pelajaran matematika merasa senang,tanpa paksaan atau dorongan dari orang lain tetapi dari diri kita sendiri untuk mencapai tujuan keberhasilan dalam pelajaran matematika.

2. Hasil belajar matematika siswa (Y), hasil yang dicapai siswa setelah memalui proses belajar mengajar pada pelajaran.Dengan hasil belajar yang di ambil dalam bentuk skor (nilai ujian tengah semester).

\subsection{Prosedur Penelitian}

Prosedur yang digunakan dalam pengumpulan data untuk variable $\mathrm{X}$ (minat belajar) dan $\mathrm{Y}$ (hasil belajar matematika) adalah data yang di komunikasi tidak langsung dengan menggunakan pengumpulan data primer atau angket. Sedangkan untuk hasil belajar, teknik yang digunakan adalah 
dokumentasi dan juga mengambil data sekunder dari tempat penelitian atau dari nilai raport semester ganjil.

Instrumen minat belajar siswa dikembangkan dengan cara menyusun butir-butir di berpatokan pada indikatot-indikator dari variabel minat belajar matematika. Instrumen atau angket minat belajar merupakan kombinasi dari beberapa angket. Jumlah item semuanya ada 55 butir dengan penyebarannya pada setiap indikator.

Tabel 1. Skala Rikert

\begin{tabular}{|l|l|l|l|}
\hline \multicolumn{2}{|c|}{ Pernyataan Positif } & \multicolumn{2}{c|}{ Pernyataan negatif } \\
\hline Sangat Setuju & 5 & Sangat Setuju & 1 \\
\hline Setuju & 4 & Setuju & 2 \\
\hline Ragu-ragu & 3 & Ragu-ragu & 3 \\
\hline Tidak setuju & 2 & Tidak setuju & 4 \\
\hline Sangat tidak setuju & 1 & Sangat tidak setuju & 5 \\
\hline
\end{tabular}

\subsection{Analisis Data}

Teknik yang digunakan dalam penelitian ini adalah teknik analisis regresi sederhana dan korelasi. Hubungan linear antara dua peubah $\mathrm{X}$ dan $\mathrm{Y}$ diduga dengan koefisien korelasi contoh yang dinotasikan dengan $\mathrm{r}$, dan dirumuskan dengan :

$$
r=\frac{n \sum_{i=1}^{n} x_{i} y_{i}-\left(\sum_{i=1}^{n} x_{i}\right)\left(\sum_{i=1}^{n} y_{i}\right.}{\sqrt{\left[n \sum_{i=1}^{n} X_{i}^{2}-\left(\sum_{i=1}^{n} X_{i}\right)^{2}\right]\left[n \sum_{i=1}^{n} y_{i}^{2}-\left(\sum_{i=1}^{n} y_{i}\right)^{2}\right]}}=b \frac{s_{x}}{s_{y}}
$$

Pengujian hipotesis dengan asumsi bahwa kedua peubah acak $\mathrm{X}$ dan $\mathrm{Y}$ masing-masing menyebar normal. Uji hipotesis dapat didasarkan pada [4]:

$$
t=\frac{r \sqrt{n-2}}{\sqrt{1-r^{2}}}
$$

yang merupakan nilai sebaran $\mathrm{t}$ dengan derajat bebas $v=\mathrm{n}-2$.

\section{Hasil dan Pembahasan}

\subsection{Deskripsi Data}

Hasil deskripsi data responden variabel yakni minat belajar (X), dan hasil belajar (Y) diuraikan sebagai berikut :

a. Pada data minat belajar untuk kelas XI IPA berjumlah 25 siswa yang mengisi angket diperoleh hasil untuk : rata-rata (mean) sebesar 112.4 ; titik tengah (median) sebesar 130; nilai yang sering muncul (modus) sebesar 122 .

b. Pada data hasil belajar untuk kelas XI IPA berjumlah 25 siswa nilai raport diperoleh hasil untuk : rata-rata (mean) sebesar 83.0404; titik tengah (median) sebesar 87.67 ; nilai yang sering muncul (modus) sebesar 87.67.

c. Pada data minat belajar untuk kelas XI IPS berjumlah 30 siswa yang mengisi angket.diperoleh hasil untuk : rata-rata (mean) sebesar 104.0667 ; titik tengah (median) sebesar 109 ; nilai yang sering muncul (modus) sebesar 108.

d. Pada data hasil belajar untuk kelas XI IPS berjumlah 30 siswa nilai raport diperoleh hasil untuk : rata-rata (mean) sebesar 78.456 ; titik tengah (median) sebesar 77.00; nilai yang sering muncul (modus) sebesar 78.00.

Untuk lebih jelas dapat dilihat pada tabel 2.

Tabel 2. Deskripsi data

\begin{tabular}{|l|l|l|l|l|}
\hline Ukuran & $\begin{array}{l}\text { Minat belajar } \\
\text { kelas XI IPA }\end{array}$ & $\begin{array}{l}\text { Hasil belajar } \\
\text { kelas XI IPA }\end{array}$ & $\begin{array}{l}\text { Minat belajar } \\
\text { kelas XI IPS }\end{array}$ & $\begin{array}{l}\text { Hasil belajar } \\
\text { kelas XI IPS }\end{array}$ \\
\hline Mean & 112.4 & 83.0404 & 104.0667 & 78,456 \\
Median & 130 & 87.67 & 109 & 77.00 \\
Modus & 122 & 87.67 & 108 & 78.00 \\
\hline
\end{tabular}




\subsection{Uji Kenormalan}

Uji kenormalan merupakan syarat yang harus dipenuhi dalam analisis data. Hasil uji kenormalan dapat dilihat pada gambar 1.

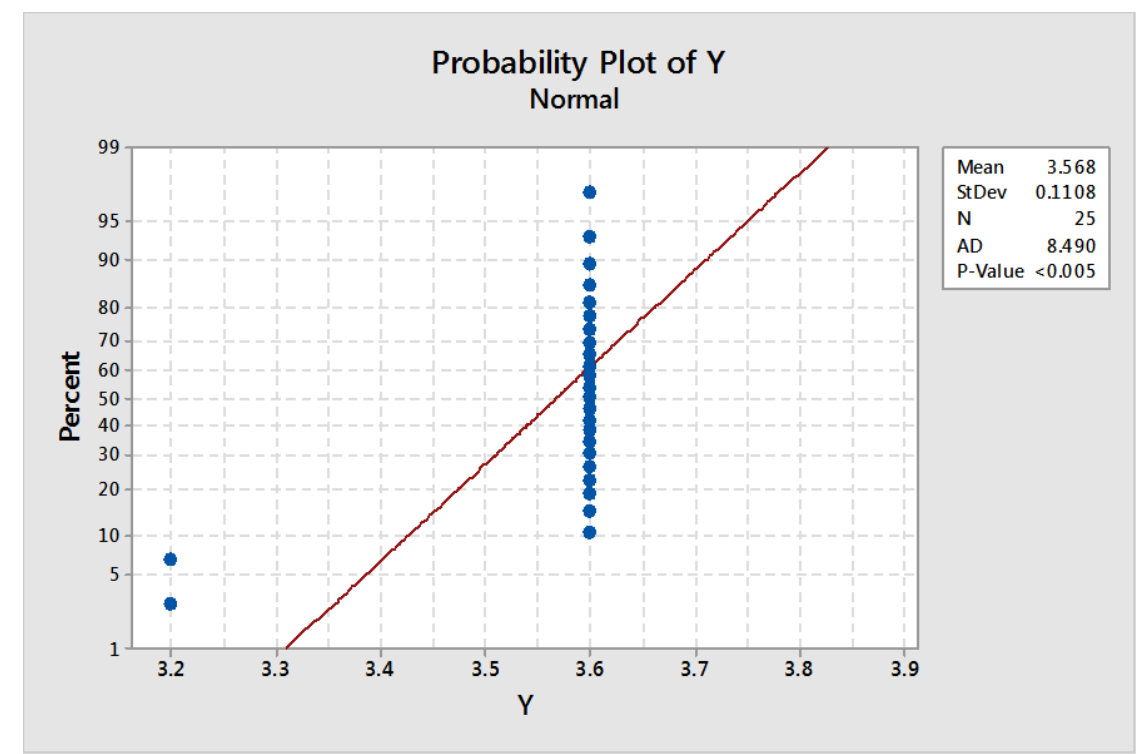

Grafik 1. Hasil analisis uji kenormalan data kelas XI IPA

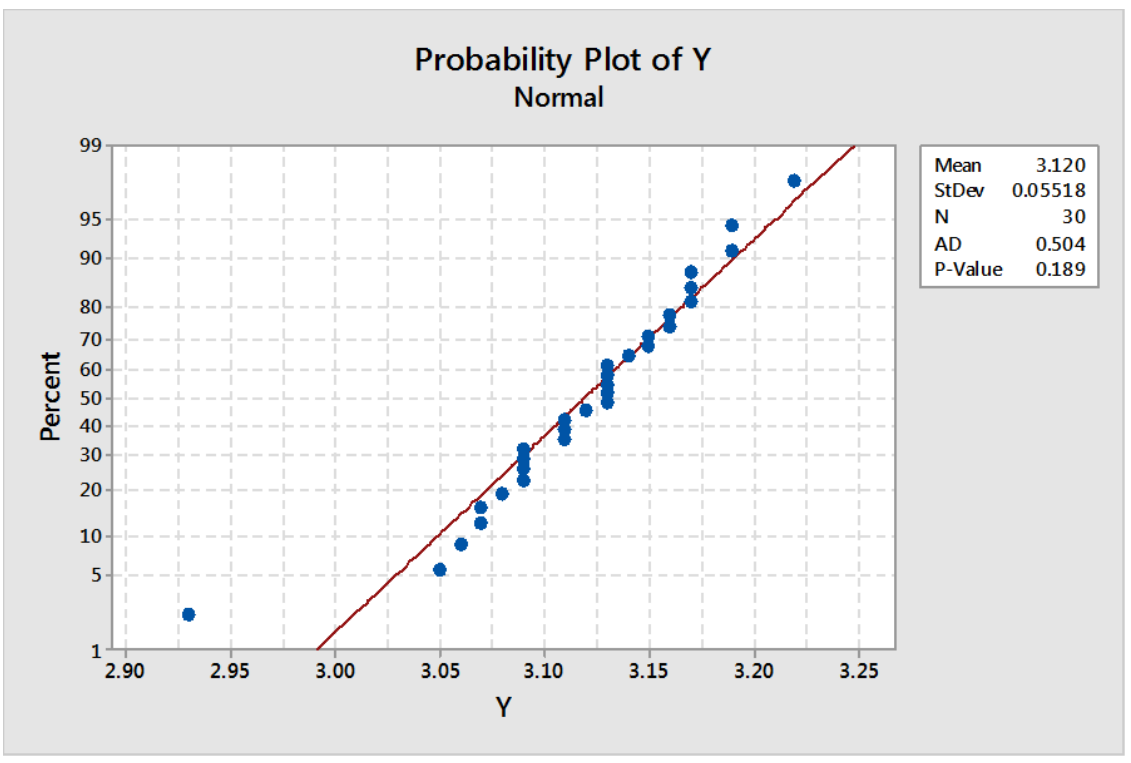

Grafik 2. Hasil analisis uji kenormalan data kelas XI IPS

Hasil analisis data kelas XI IPA pada (grafik 1) dapat diketahui bahwa datanya menyebar normal dimana $\alpha=0.005<p_{\text {value }}=0.005$, dan hasil analisis data kelas XI IPS pada (grafik 2) dapat diketahui bahwa datanya menyebar normal dimana $\alpha=0.005<p_{\text {value }}=0.189$.

\subsection{Uji Hipotesis}

Hasil analisis hubungan antara minat belajar dan hasil belajar matematika siswa SMA Kristen Eben Haezer Ibu diperoleh nilai koefisien korelasi $r=0.063$ untuk kelas XI IPA dan $r=0.303$ untuk kelas XI IPS. Uji hipotesis untuk kelas XI IPA menunjukkan $\left(t_{\text {hitung }}=0.303\right)<\left(t_{\text {tabel }}=1.7138\right)$ dan kelas XI IPS menunjukkan $\left(t_{\text {hitung }}=1.68\right)<\left(t_{\text {tabel }}=1.70113\right)$. Artinya, secara statistik menyatakan tidak ada hubungan secara signifikan antara minat belajar dan hasil belajar matematika. 

berikut :

Analisis regresi untuk data kelas XI IPA dan data kelas XI IPS diperoleh persamaan sebagai

1. Kelas XI IPA : $\mathrm{Y}=3.595-0.00024 \mathrm{X}$

2. Kelas XI IPS : $\mathrm{Y}=3.294-0.001653 \mathrm{X}$

Keterangan : X minat belajar siswa dan $\mathrm{Y}$ hasil belajar siswa

\section{Kesimpulan}

Kesimpulan yang dapat ditarik berdasarkan hasil analisis dan pembahasan, sebagai berikut :

1. Guru matematika harus berusaha menciptakan suatu proses pembelajaran yang inovatif sehingga dapat memberikan dorongan dan motivasi kepada para siswa untuk belajar matematika.

2. Hasil analisis hubungan antara minat belajar dan hasil belajar matematika siswa SMA Kristen Eben Haezer Ibu diperoleh nilai koefisien korelasi $r=0.063$ untuk kelas XI IPA dan $r=0.303$ untuk kelas XI IPS.

3. Hasil analisis regresi untuk kelas XI IPA dan kelas XI IPS diperoleh persamaan
a. $\quad$ Kelas XI IPA : $\mathrm{Y}=3.595-0.00024 \mathrm{X}$

b. $\quad$ Kelas XI IPS : Y $=3.294-0.001653 \mathrm{X}$

4. Uji hipotesis, kelas XI IPA dan kelas XI IPS secara statistik menyatakan tidak ada hubungan secara signifikan antara minat belajar dan hasil belajar matematika.

\section{Daftar Pustaka}

[1] Yushanafi M. 2012.http://jurnal.skripsi/2012/perbedaan-minat-dan- prestasi-belajar-siswa-padamata-diklat-mengoperasikan-sistem-pengendali-elektronik-dengan-menggunakan-softwaretutorial-plc/.2012

[2] Sukmadinata.2005. Landasan Psikologi Proses Pendidikan.PT. RemajaRosdakarya. Bandung.

[3] Hatidja, J. 2006. Bahan Ajar Analisis Regresi. Universitas Sam Ratulangi . Manado

[4] Walpole, R. E. 2005. Pengantar Statistik. Edisi ke-3: PT. Gramedia Pustaka Utama. Jakarta. 